\title{
INTRODUCTION TO PAYMENT SERVICES: LAW AND PRACTICE
}

\author{
John Casanova and Max Savoie
}

A. INTRODUCTION 1.001

\section{A. INTRODUCTION}

When we agreed to produce and edit this book in the early autumn of 2019, we had no idea how much the EU and the UK - or indeed the world - were about to change with the outbreak of the COVID-19 pandemic. While the long-term effects of the pandemic on the world in which we live remain to be seen, in terms of payment services it certainly has accelerated growth in the already developing sector of online payment services, as we all worked and shopped from home. ${ }^{1}$ The pandemic has also done more to move the UK and the EU into a cashless payment environment for retail in-person payments than anything seen since the introduction of card payments in the later half of the twentieth century. Indeed, rather than struggling to find our odd coins and bills at the till, we now struggle to see if the facial recognition features of our phones will work through our masks and allow us to tap and go. ${ }^{2}$

The other seismic event affecting payment services, at least for the UK, has of course been the impact of a relatively hard Brexit that has made little allowances for financial services, let alone payment services. With Brexit, while we had always intended to cover both the UK and the EU, as we go to publication

1 Kalle Dunkel, 'How COVID-19 is reshaping retail payments in Europe' (EY, 17 June 2020) available at: www.ey.com/en_gl/banking-capital-markets/how-covid-19-is-reshaping-retail-payments-in-europe.

2 ibid. 
we have had to deal with much more drift between the two regulatory regimes than we had anticipated. ${ }^{3}$

1.003 Of course, COVID-19 and Brexit are not the only drivers of recent developments in payment services. The rise of fintech in all its forms has been perhaps the most persistent driver of development and innovation in the sector. In this regard, we have seen the rise of the mobile app for banking, payment and other financial services, first as limited supplements to website-based services and now more and more in replacement of them; the introduction of new payment methods by various card networks, including for business-to-consumer and consumer-to-consumer payments, effectively repurposing existing payment rails for new services; the introduction of new alternative payment methods that afford consumers and businesses more choices on how to pay for and finance purchase transactions; ${ }^{4}$ and the rise of open banking, which provides consumer and business users more flexibility than ever in managing their payments through the use of third party service providers. ${ }^{5}$ In terms of the hardware (necessarily loosely defined) supporting these developments, we have seen over the past several years progressive developments in payment devices, from cards (and with cards going from strip to chip and now to virtual), to mobile phones, to wearables and perhaps soon to voice and other biometric methods of initiating and approving payments. ${ }^{6}$ Indeed, for businesses and consumers, there is more choice than ever in where we pay, how we pay and when we pay for goods and services.

1.004 Against the backdrop of these developments, regulators too have been at work. While the implementation of the second EU Payment Services Directive $(\mathrm{PSD} 2)^{7}$ in the UK and the EU is hardly a new development, regulatory guidance, enforcement actions and even some case law around PSD2 have been part of a growing body of regulatory materials applicable to payment services in the EU and the UK. ${ }^{8}$ More recently, the European Central Bank (ECB) has implemented a new oversight framework for electronic payment instruments,

3 See for example the regulation of cryptocurrencies discussed in Chapter 7.

4 For example Klarna, Clearpay and Laybuy.

5 See discussion of account information service providers and payment initiation service providers in Chapter 3.

6 Hakan Eroglu, 'How will biometrics balance payment security \& convenience under PSD2?' (Accenture, 19 July 2018) available at: https://bankingblog-accenture.com/biometrics-balance-payment-security-convenience -psd2.

7 Directive (EU) 2015/2366 of the European Parliament and of the Council of 25 November 2015 on payment services in the internal market, amending Directives 2002/65/EC, 2009/110/EC and 2013/36/EU and Regulation (EU) No 1093/2010, and repealing Directive 2007/64/EC [2015] OJ L337/35; see section B 'Payment Services Directive - PSD2' of Chapter 3.

8 FCA, 'Coronavirus and safeguarding customers' funds: additional guidance for payment and e-money firms' (9 July 2020) available at: www.fca.org.uk/publications/finalised-guidance/coronavirus-safeguarding 
schemes and arrangements, ${ }^{9}$ while in the UK, the Financial Conduct Authority (FCA) has been making good on its announcement in its 2020-1 business plan that payment services were one of its main supervisory priorities. ${ }^{10} \mathrm{In}$ addition to these regulatory initiatives directly focused on payment services, there have been significant regulatory developments dealing with anti-money laundering, data protection and the regulation of cryptocurrencies, all of which have a direct impact on payment services. ${ }^{11}$

Addressing all these market and regulatory developments in what we hope is a cohesive legal reference book has not been without its challenges, particularly given the wide range of issues for possible coverage and a subject matter that moves with alacrity. To address this, we have divided the book into three sections. The first section covers the development and direct regulation of payment services in the EU and the UK. We start this section with a chapter that explores the regulatory and historical context in which payment services and fintech have developed in the EU and the UK, and is very much an anchor piece for the book. Rounding out this section are two chapters that set out in detail the specific regulatory regimes in the EU and the UK for payment service providers and payment systems.

The second section of the book explores the other legal, regulatory and market issues that affect payment services. In this section we have included chapters on financial crime, anti-money laundering and regulatory enforcement; data protection and cyber security; crypto currencies and related technologies; and competition issues. As can be seen in these chapters, regulatory and legal developments in these areas are becoming increasingly important for payment services - so much so that some of the more significant regulatory developments in these areas are driven specifically by developments in payment services.

-customers-funds-additional-guidance-payment-e-money-firms; see further paragraph 3.07 of Chapter 3 for guidance and case law on the meaning of 'payment account'.

9 ECB, 'Eurosystem oversight framework for electronic payment instruments, schemes and arrangements' (November 2021) available at: https://www.ecb.europa.eu/paym/pdf/consultations/ecb.PISApublicconsultation202111_1.en.pdf.

10 In May 2021 the FCA reminded e-money firms to make it clear to customers how their money is protected (see FCA, 'Dear CEO letter: ensure your customers understand how their money is protected' (18 May 2021) available at: www.fca.org.uk/publication/correspondence/dear-ceo-letter-e-money-firms.pdf); and in April 2021 the FCA struck off an authorised payment institution for failing to meet its authorisation conditions (see FCA, 'Second Supervisory Notice - Newport Services (UK) Ltd' (13 April 2021) available at: www.fca .org.uk/publication/supervisory-notices/second-supervisory-notice-newport-services-uk-ltd.pdf).

11 See Chapters 5 'Financial Crime and Enforcement against Payments Firms and Payments Systems', 6 'Payments and EU Data Protection Law' and 7 'Payments and Blockchain/Crypto-Assets'. 
1.007 Finally, while our focus here is on the EU and the UK, it would be remiss not to note that the ethereal nature of payment services means that they and those that offer them are less tied to physical 'bricks and mortar' bases than are many other types of financial services. Thus, our final section is a sampler on how payment services are regulated under other jurisdictions. The section begins with a chapter on payment services in the United States, where the regulatory regime provides an interesting counterpoint to the EU and UK regimes. Next are chapters on the regulation of payment services in Hong Kong and Singapore. Both jurisdictions are important markets for payment fintech innovation, not just within-country but also regionally and internationally. In addition, both jurisdictions have incorporated elements of the EU regulatory regime into their own. Finally, we conclude with a chapter on the development and regulation of payment services in Sub-Saharan Africa, primarily in Kenya, where the development of M-Pesa has attracted global attention, and rightly so. As this chapter demonstrates, local innovation in payment services continues to be a key driver of financial inclusion and e-commerce in the region. This chapter, as with those on Hong Kong and Singapore, also shows how innovative regulators can take the better elements of other regulatory regimes, while at the same time ensuring further innovation and flexibility to meet the needs of their own market. 